Kimmitt J, Munoz P. Entrepreneurship and financial inclusion through the lens of instrumental freedoms. International Small Business Journal: Researching Entrepreneurship 2017, 35(7), 803-828.

DOI link

https://doi.org/10.1177/0266242617700699

ePrints link

http://eprint.ncl.ac.uk/pub details2.aspx?pub id=219061

Date deposited

$06 / 12 / 2017$

Copyright

Copyright @ 2017 SAGE Publications. Reprinted by permission of SAGE Publications 


\title{
ENTREPRENEURSHIP AND FINANCIAL INCLUSION THROUGH THE LENS OF INSTRUMENTAL FREEDOMS
}

\begin{abstract}
This paper investigates the interrelated nature of instrumental freedoms and how they combine to engender financial inclusion amongst low income entrepreneurs. Drawing from Sen's capabilities approach, we emphasize a need for understanding the freedoms associated with institutional arrangements and the complex causal processes that lead to financial inclusion amongst micro-entrepreneurs. We perform a Fuzzy Set Qualitative Comparative Analysis of 19 countries in Latin America and the Caribbean. The findings indicate four causal combinations for financial inclusion. Our findings indicate that no single instrumental freedom is necessary for financial inclusion; it does not necessarily depend on the provision of microfinance and that political freedom is an important peripheral condition for inclusion. This allows us to question some of the assumptions about how microfinance operates amidst a set of complex institutional instrumental freedoms.
\end{abstract}

Keywords: instrumental freedoms; financial inclusion; institutions; microfinance; fs/QCA 


\section{Introduction}

Microfinance represents a method of financial inclusion that integrates individuals into the formal financial system (Yunus, 1999), which is widely considered to foster entrepreneurial activity such as new business creation (Attanasio et al., 2015; Augsburg et al., 2015; Shahriar, Schwarz and Newman, 2015), growth (Ferdousi, 2015; Field et al., 2013) and improved personal income for entrepreneurs (Chliova, Brinckmann and Rosenbusch, 2015). Such inclusive methods to facilitating entrepreneurship "aspire to create opportunities that enhance social and economic well-being for disenfranchised members of society" (George et al. 2012, p. 663). Despite the research and policy emphasis on microfinance and financial inclusion (Ansari, Munir, and Gregg, 2012; Demirgüç-Kunt, Asli, and Klapper 2012), and how it fosters entrepreneurial activity (Bruton, Khavul, and Chavez, 2011; Bradley McMullen, Artz, and Simiyu, 2011; McMullen 2011), we still know very little about the conditions under which this flourishes amongst this population of micro-entrepreneurs (i.e. the provision of microfinance services to the entrepreneurial poor), in particular those conditions related to the complex set of institutional instrumental freedoms an entrepreneur experiences. In this context, we seek to answer the following question: how do the interrelated nature of instrumental freedoms combine to engender financial inclusion amongst micro-entrepreneurs?

Increasingly, entrepreneurship scholars have identified the interrelationship between entrepreneurs and their (institutional) contexts (Lang, Fink and Kilber, 2013; Welter, 2011; Williams and Vorley, 2014; Zahra, Wright, and Abdelgawad, 2014). In this vein, one consistent theme in the literature is microfinance's relationship with institutions, based on the premise that the development of a sound financial system requires support from other 
aspects of the institutional context (e.g. legal/regulatory) which influences how entrepreneurial finance is channeled to micro-entrepreneurs in developing economies (Eid 2005; Levine, 1998; Shleifer, 1997). However, current efforts reduce institutional explanations to the effects of their individual components; how the legal protection of lending activities and ease of starting a business influences an MFIs willingness to fund start-ups (Shahriar, Schwarz and Newman, 2015); the impact that a country's regulatory environment has on the performance of MFIs in periods of financial crisis (Silva and Chávez, 2015); the willingness of entrepreneurs to borrow from MFIs depending on the strength of political or economic institutions (Kimmitt, Scarlata and Dimov, 2016); or the moderating effect of different aspects of institutions on entrepreneurial outcomes (Chliova et al., 2015). This is problematic because it does not consider institutional elements together, which is central to further understanding how contexts, holistically, constrain or facilitate human agency and how agency and institutional complexity interact with each other (Greenwood, Raynard, Kodeih, Micelotta, and Lounsbury, 2011; Munoz and Kibler, 2016). In addition, given the limited diversity of the contexts of interest and the limitations of linear methods, empirical efforts in this area have limited analytical power and the explanations drawn from such studies are partial at best.

In this paper, we take the position that elements of institutions should be taken together in respect of their joint and complimentary importance. This builds explicitly from Sen's (1999) capabilities approach which recognizes the interrelated empirical link between different aspects of institutions which should be viewed as "instrumental freedoms". In Sen's perspective, capabilities are understood to be the freedoms a person has to achieve certain life goals and activities which are functions of their institutionally driven 
instrumental freedoms (economic facilities; political freedoms; social opportunities; transparency and protective security). Such freedoms represent critical means for capabilities as they contribute to the ability of a person to live more freely and thus "directly enhance the capabilities of people" (p.40). The ability to establish business premises without fear of harassment, having variable access to an education, enforcing terms of a contract and/or whether bribes are part of the business culture all represent examples of instrumental freedoms that may make financial inclusion for micro-entrepreneurs more or less possible. Of course, MFIs have been particularly instrumental as a type of economic facility designed to spur entrepreneurial outcomes through financial inclusion (Bruton et al., 2011; Khavul, 2010). Although there appears a well-established link between the economic facility of microfinance and the financial inclusion of entrepreneurs, we know very little about the holistic interaction between this and the other institutionally driven instrumental freedoms.

Sen's theory is holistic; thus freedoms only make sense if seen together because they are interconnected and complement each other. As such, any empirical effort aimed at examining the effect of instrumental freedoms would require combinatorial thinking and an appropriate methodological approach capable of observing and analyzing configurations of instrumental freedoms, rather than their individual effect on the outcome of interest. To examine this idea, we draw from multiple data sources from Latin America and the Caribbean to perform a fuzzy set qualitative comparative analysis - fs/QCA (Ragin, 2008). We examine Sen's $(1999 ; 2005)$ instrumental freedoms against the degree of financial inclusion amongst micro-entrepreneurs to capture the joint and interdependent effect of institutions on the use of microcredit. Our configurational assessment suggests 
that no single instrumental freedom is necessary for financial inclusion. It rather shows that financial inclusion can follow from four distinct combinations of conditions, which collectively explain how different combinations of institutional freedoms enable, and in some cases constrain, strong rates of microfinance use amongst micro-entrepreneurs. Instead of highlighting the necessary "perfect" institutional contexts for financial inclusion, our analysis shows that financial inclusion can also emerge under odd sets of conditions, in rather counterintuitive contexts lacking normally assumed necessary conditions, for example, widespread and intensive microfinance provision to entrepreneurs.

Our paper contributes to the literature in several ways. First, by looking at the distinct combination of instrumental freedoms leading to financial inclusion - assessed by means of microfinance rates amongst micro entrepreneurs in developing contexts - this paper enhances scholarly understanding of whether and how microfinance fosters inclusive activities amongst micro-entrepreneurs (George et al., 2012). Second, the theoretical propositions developed by Newman, Schwarz and Borgia (2013) argue that microfinance can produce various social and psychological outcomes at the individual level. Whilst they acknowledge that this process depends on 'microfinance provision' they do not delve into the antecedents of this inclusivity issue. Thus, this paper helps yield further insight into entrepreneurship, microfinance and institutions in emerging economy settings (Smallbone Welter, and Ateljevic, 2013). Finally, our methodological approach, combined with our theoretical lens, enables a more fine-grained understanding of particular institutional contexts, in particular of how financial inclusion amongst micro-entrepreneurs can surface from an array of combinations of instrumental freedoms - logical and counterintuitive forms - which can only be adequately observed when taken together. In doing so, our work 
overcomes the limitations of previous research at the intersection of entrepreneurship, inclusion and institutions which so far have shown pieces of puzzle, but have not yet explained how instrumental freedoms, in their present and absent forms, can uniquely (and surprisingly) combine to foster financial inclusion.

The paper is structured as follows. Firstly, we outline the distinction between institutions and instrumental freedoms before discussing prior research related to each individual freedom. Secondly, we present the methodology - a fuzzy set Qualitative Comparative Analysis - that allows us to understand the complex interactions between the freedoms and those causal combinations leading to financial inclusion. Thirdly, we discuss and interpret the configurational analysis before outlining our contribution to the literature and offering areas for further empirical work.

\section{Background Literature}

Entrepreneurship research acknowledges that entrepreneurial activity is influenced by institutions, as they determine incentive structures and shape decision-making (Baumol 1990; Bianchi, 2010; Sautet, 2013). Institutions are viewed as "the humanly devised constraints that shape human interaction" (North, 1990) with political and economic structures explaining the nature of markets and entrepreneurial action in developing economies (McMullen, 2011). These are both formal and informal, since at their basis we can find not only regulative rules, but also cognitive and normative rules, which Scott (2001) identifies as the pillars of institutions. 
In the face of the evidence that economies in developing countries have failed to grow (Easterly, 2001), scholars have established that institutions play an instrumental role in linking entrepreneurial activity with economic outcomes (Acs and Virgill, 2010). Indeed, there are long standing arguments that traditional regulatory theory, as applied to entrepreneurship in developed countries, does not readily translate to contexts where institutional weakness or 'imperfection' is prominent (Easterly and Levine 1997, North 1987, 1990, Roth and Kostova, 2003). For entrepreneurs, such institutional features produce a series of challenges with increases in transaction costs limiting the appropriability of entrepreneurial rents, which in turn reduce the perceived attractiveness of entrepreneurial opportunities and can lead to suppression of start-up activity (Baker Gedajlovic, and Lubatkin, 2005). What is overwhelmingly clear from extant research is that particular types of institutional arrangements provide entrepreneurs with a set of conditions that shape their judgments and actions they take.

Similarly, notions of 'capacity building' or 'institutional strengthening' have been a valid feature of development policy in recent times (e.g. Eade, 2007). However, the current view of institutions within the literature is problematic in a context of financial inclusion because it assumes the need for a particular set of institutional arrangements which has little account for freedoms within those settings. Institutional development is often viewed as an important outcome of structural development with the presumption that when the institutions are "right" this leads to a particular set of desirable outcomes (e.g. financial inclusion and poverty reduction). Sen (2009) describes this position as 'transcendental institutionalism' that ignores the complex interrelations between institutions and the actual freedoms individuals and entrepreneurs experience (Sen, 2009). In Sen's (1999) view, 
there exist important empirical connections between different elements of institutions that can produce varying outcomes and if we take the transcendental view then we may ignore the multiple pathways to (un)desirable outcomes. This suggests that a search for a perfect recipe for institutional conditions that leads to financial inclusion is misguided.

To understand the complex drivers of development, Sen $(1999 ; 2005)$ proposed the use of a 'capabilities approach' to poverty which shifts poverty analysis onto the nonmonetary factors that produce development outcomes. According to Sen, poverty alleviation concerns enabling a person's freedoms or understanding what is constraining their freedoms to realize certain goals and activities which comprise their livelihood (Alkire, 2005) and 'what they do' (Anand et al., 2009). The underlying philosophy of this approach is to tackle the assessment of development and growth through the use of traditional economic measurable estimators, mainly gross domestic product or household income.

One of the key concepts in the capabilities approach is 'achieved functionings'. Functionings substantively reveal what a person does and the choices that they actually make and is the typical analytical focus in the capabilities approach (Anand et al., 2009). Functionings is an umbrella term for the resources and activities recognized as making up a person's wellbeing (Alkire, 2005). In this capabilities perspective, an entrepreneur's use of microcredit is seen as a functioning in the sense that it represents an expansion of freedoms based on their ability to use resources and pursue entrepreneurial activities they previously were not able to (Gries and Naudé, 2011). In this respect, financial inclusion represents an expansion of capabilities for micro-entrepreneurs. 
But these capabilities are guided by and intertwined with institutional arrangements. These institutional arrangements determine an individual's political freedoms, access to economic facilities, social opportunities and so forth (Sen, 2005; Nussbaum, 2000). Substantive freedom, understood as the enhancement human capabilities, is both the end and the means of development. Freedom, in Sen's view, is not a single entity. It rather manifests itself through five distinct institutional instrumental freedoms: 1) economic facilities; 2) protective security 3) political freedoms; 4) social opportunities; and 5) transparency. These freedoms are complementary and mutually reinforcing and of particular analytical importance because of their instrumental function that allows for enhanced functionings. They represent a more useful focus for poverty analysis into financial inclusion because they take into account the freedoms an individual actually experiences in their institutional context and the complex interrelations between these types of freedom.

\section{Instrumental Freedoms and Financial Inclusivity}

In terms of economic facilities (i.e. financial services), research demonstrates that the underdevelopment of the financial sector can lead individuals into 'poverty traps' (Berthelemy and Varoudakis, 1996). They can constrain individuals from pursuing a particular course of action from a number of alternatives (Sen, 2005). Indeed, this is reflected in World Bank data which demonstrate that access to finance is the single most pervasive issue facing both individuals and businesses in Sub-Saharan Africa, with 41.2\% of small businesses revealing credit constraints more so than any other region in the world (Beck and Demirgüç-Kunt, 2008; Honohan, 2007). Thus, a lack of access to economic 
facilities distorts a person's ability to pursue the life goals they value, to freely choose amongst life options and have the necessary agency to do so (Alkire, 2005; Gries and Naudé, 2011).

This instrumental freedom is directly relevant to financial inclusivity and the microfinance sector. The purpose of MFIs is to directly address the absence of this instrumental freedom by providing entrepreneurs with access to small loans for the development of their ventures. Through stimulated entrepreneurial activity, the logic is that poor individuals will be able to more effectively be able to participate in economic exchange. The social impact of entrepreneurial activity has been largely documented by prior research and presented as a vital part of social development as well as economic growth (Minniti and Lévesque, 2010), and societal change (Acs and Virgill, 2010; Schumpeter, 1934), all antecedents to poverty eradication (Helms, 2006; Dollar and Kraay, 2002; Chliova et al., 2015; Venkataraman, 1997). The basic premise of microfinance, therefore, is that financial inclusion is an important functioning for a micro-entrepreneur. However, we know very little about how this approach to inclusivity is empirically connected to the other critical instrumental freedoms identified by Sen.

In terms of protective security, Baker et al. (2005) highlight how nations with such securities in place (e.g. strong welfare systems) tend to have lower levels of entrepreneurial activity than those without. In their absence, individuals who may otherwise use state support may be pushed into entrepreneurship out of necessity when paid opportunities for unemployment are unavailable (Acs and Virgill, 2010). Developing economies are characterized by serious income insecurity, meaning that it is not simply about a lack of income but inconsistency in terms of when that income arrives (Banerjee 2007). This 
makes the provision of safety nets particularly critical. This is particularly pertinent to microfinance where the group-lending format typically provides a supportive environment when entrepreneurs find themselves in financial difficulty (Webb et al., 2010; Yunus, 1999). In addition, in a microfinance context the concepts of protective security and economic facilities are closely linked because of how they improve the financial security of individuals.

In terms of political freedoms, Acemoglu and Robinson (2012) argue that the development of inclusive economic institutions is preceded by the adequate development of inclusive political systems. Political institutions which are 'extractive' (e.g. autocratic rule/weak governance) tend to block socio-economic innovation which leads to long term non-inclusive consequences. These institutions can create markets which function effectively (i.e. China) but the political system, governed by minority rule or elitism, offers little or no incentive for innovative entrepreneurial firms (Bradley et al., 2012; Schumpeter 1934). From an entrepreneur's view, Kimmitt et al. (2016) identify that under-developed political institutions lead firms to borrow more microcredit and Chliova et al. (2015) highlight that women's empowerment is more profound amongst microcredit entrepreneurs where there are greater political freedoms. Thus, the political freedoms associated with a particular context can have distinct manifestations for how entrepreneurs access and use microcredit. Sen (1999) particularly highlights that political freedoms tend to be closely associated with economic freedoms because a freedom of expression and action are important for individuals to make the most of their economic freedoms.

In terms of social opportunities, according to Sen (1999, p.39) the adequate provision of education reflects an important social opportunity which give individuals the 
"substantive freedom to live better". In developing economies, education is particularly critical because of how it assorts individual into particular labor roles (Baker et al., 2005). Berkowtitz and De Jong's (2005) study on the relationship between economic growth and entrepreneurship demonstrated a positive effect of education on entrepreneurial outcomes. However, education's assortment of roles, as identified by Baker et al. (2005), produces inequalities through social stratification. For example, during South Africa's apartheid regime state institutions ensured the promotion of educational rights for white minorities thus reducing the social mobility of the black population and entrenching social inequalities (Seidman 1999). Additionally, Buchmann and Hannum (2001) demonstrate that educational stratification determines occupational attainment and social mobility which are synonymous with family background.

Baker et al. (2005) refer to this as social stratification; i.e. institutional processes which partition society into advantaged and disadvantaged groups which is at the heart of inequality (Robinson, Blockson, and Robinson, 2007). These are structural level differentiations within society where it is typically difficult for an individual to be able to move from a lower to an upper stratum because of inequalities (Ravlin and Thomas 2005). This perspective suggests that as a result of these processes, large portions of the labor force in developing economies take up certain economic roles and are therefore exposed to certain experiences or 'knowledge corridors' (Ronstadt, 1988). Thus, widening access to education, as an instrumental freedom, lends itself to generally more inclusive economic and social outcomes (Acs and Virgill 2010; Baker et al., 2005; Martinelli 1994). This is consistent with recent studies from developing economies which emphasize that inclusivity requires sufficient expertise and knowledge in conjunction with access to financial capital 
(Bradley et al., 2012). Given the approach adopted by some MFIs, to provide financial and/ or business training to micro-entrepreneurs, we would expect to see this to be an important instrumental freedom for financial inclusion. Simultaneously, education levels are likely to represent important tangible proxies for loan officers in their selection decisions (Bruns, Holland, Shepherd, and Wiklund, 2008; Canales, 2014).

In terms of transparency, research has consistently highlighted a link between corruption and capabilities. In corrupt environments, individuals' capabilities are exacerbated which can distort incentives for entrepreneurial action (Budak and Rajh, 2014; Gupta, Davoodi, and Alonso-Terme, 2002). Further reduction in such incentives results from the harassment associated with trading (Fadahunsi and Rosa, 2002), scaling down of the financial capital needs of entrepreneurs (Takyi-Asiedu, 1993), and a more general reluctance to invest in growth projects (McMillan and Woodruff, 2002). In addition, corruption is closely tied with the legal framework of a nation. Legal constraints erode profit making incentives for firms (Hoffman, 1999). Well-developed legal environments reduce uncertainties for firms, allowing them to form expectations about future performance (McMullen, 2011; Scully, 1988). Indeed, Silva and Chávez (2015) show that rule of law is particularly critical for MFI performance and outreach. Therefore, we would expect to see transparency as an important explanatory factor for inclusive microfinance activity amongst micro-entrepreneurs.

In summary, we can observe the significance of each of Sen's instrumental freedoms within their own right. Individually, we have seen numerous empirical observations that highlight their role in developing inclusive development outcomes i.e. access to microcredit. However, we know very little about the empirical connections between each 
freedom in relation to inclusivity - stressed by Sen $(1999 ; 2005)$ as being of vital importance to understanding the relationship between institutions and capability outcomes. Using a capability lens, Chliova et al. (2015) suggest that microcredit use may be more pronounced in contexts of lower instrumental freedoms. When unpacking this relationship, they only consider each instrumental freedom individually without taking into account the mutually reinforcing connections between freedoms of different kinds, as was originally intended by Sen. Moreover, much of the extant research has focused on the supply (e.g. Mair and Marti, 2009; Khavul et al., 2013) or demand side (e.g. Kimmitt et al., 2016) of microfinance activity without recognizing that financial inclusivity occurs in a space of both provision by MFIs and microcredit use by entrepreneurs. Thus, in this paper we ask, how do the interrelated nature of instrumental freedoms combine to engender financial inclusivity for micro-entrepreneurs?

\section{Methodology}

\section{Methodological approach}

In looking at how instrumental freedoms combine to produce financial inclusion in a developing context, this research draws on the strengths of fuzzy set qualitative comparative analysis - fs/QCA (Ragin, 2008). fs/QCA is a set-theoretic method that permits visualizing and analyzing complex causality and testing the necessity and sufficiency of particular conditions and combinations of conditions (Ragin 1999).

By using Boolean algebra, counterfactual analysis and logical minimization, fs/QCA allows for comparing cases as configurations of factors (Ragin 2000), observing empirical 
information in a more parsimonious manner, and subsequently making causal interpretations based on the logic of causal necessity and sufficiency (Schneider and Wagemann 2012). In doing so, it systematically compares different combinations of causal and outcome conditions (Ragin 2008a) to finally produce simplified combinations of causes that collectively explain the outcome under examination. Instead of searching for antecedent common conditions shared by all instances of the outcome - as traditional approaches to causal explanations do - fs/QCA focuses on and allows for equifinality, i.e. the possibility that the same outcome can follow from different combinations of conditions (Ragin, 2008). As a method and analytical technique originally developed for conducting cross-country comparisons, fs/QCA permits assessing robustly the necessity and sufficiency of conditions with a small number of cases (Leiberson, 1991). This is particularly relevant when cases are by nature small in number and the phenomenon is either episodic or unique to a specific context. These empirical contexts are restricted to alternative multivariate analyses such as cluster analysis or structural equation modeling, which require a large number of observations to robustly produce groups or estimate structural relationships.

While fs/QCA focuses on identifying key recipes for a particular outcome, it does not ignore specific patterns and outliers. If a particular combination of conditions explains only single case, it is not considered as less relevant than other combination of conditions that explain the large majority of cases (Rihoux and Ragin 2008). Such case is not treated as an error or prematurely discarded, as traditional statistical analysis would do. This outlier situation simply illustrates that the outcome of interest can emerge under an odd 
combination of conditions. Such a discovery is empirically rich and theoretically relevant, and particularly pertinent to our discussion of Uruguay (see below).

\section{Case selection and data collection}

Case selection in fs/QCA studies relies on a tentative and iterative process and is based on two key criteria: sufficient homogeneity and maximum heterogeneity (Rihoux and Ragin, 2008). First, it requires an area of homogeneity, with cases sharing similar background characteristics. Second, within that area maximum heterogeneity of cases is required in terms of positive and negative outcomes. Case selection in fs/QCA does not rely on mechanistic procedures, such as random sampling, but rather on a tentative and iterative process where the criteria of sufficient homogeneity and maximum heterogeneity are constantly pursued (Rihoux and Ragin 2008). The non-parametric nature of fs/QCA reduces the risk of sample selection biases (Fiss 2011), which generally affect research requiring random sampling (Berk 1983).

Based on fs/CQA criteria and data availability and reliability, the research team purposively selected 19 countries (out of 32 in the region) from Latin America and the Caribbean (see Table 2 below). This region presents a distinct combination of history, culture, societal structures, political institutions and revolutions. Although most of the current political and economic institutions have been inherited from Europe during Latin America's independence processes 200 years ago, the combination of these institutional forms with the local culture led to successive waves of reform, often resisted and superseded rather than fully assimilated, which transformed the socio-economic structure of this region into a unique mosaic of factors combining the politics of expertise, 
privatization, poverty and inequality, and citizenship insecurity (Whitehead, 2006). Latin America and the Caribbean as a whole is the world's fourth largest economy, yet the most unequal region in the planet. In 2014 the richest 10 per cent of people in Latin America concentrated 71 per cent of the region's wealth, and most of this wealth is held offshore in tax havens (World Economic Forum, 2016).

The data we used in this study stems from several publicly available sources, such as IDB Multilateral Investment Fund's Financial Inclusion Report 2014, United Nations' Human Development Report, Gallup World Poll and Transparency International. In other to capture and assess the same background conditions, all data used in this study were collected during 2014 and reported in 2015.

\section{Measurement}

Economic facilities (freedom) and protective security were captured by looking at the provision of microfinance (MICROFINANCE) per country measured by microfinance US dollars available per inhabitant (US\$MF/Hab). We combined economic freedom with protective security because the provision of microfinance loans tends to be interwoven with the use of savings, thus providing entrepreneurs with an income safety net i.e. protective security. In addition, in Latin America and the Caribbean, deposits represent the main source of funding in the region with the vast majority of deposits for MFIs stemming from voluntary (rather than compulsory) savings of their clients as conditions of existing or future loans ${ }^{1}$ (MIX Market, 2015). This demonstrates that the micro-entrepreneurs in our

\footnotetext{
${ }^{1}$ The Microfinance Market and Trends in Latin America and the Caribbean (2015) report indicates that $73 \%$ of an MFI's funding in the region comes from voluntary savings as tied to current or future access of a loan. $1 \%$ of MFI income as tied to current or future access of a loan is compulsory. The additional $26 \%$ represents income sources from institutions such as corporations, other financial institutions, or government agencies and is therefore not linked to client micro-entrepreneurs.
} 
sample population are accessing and using loans whilst simultaneously making use of the savings products offered by MFIs; therefore experiencing economic freedom and protective security (of a safety net) together. In this sense, MFIs perform the role of a "protoinstitution" by providing economic freedom and protective security to entrepreneurs in times of need (Webb et al., 2010). For the sake of simplicity, we just use the terms economic freedom or microfinance throughout the rest of the paper.

We constructed the measure by estimating the specific market size for microfinance, dividing the country's portfolio size by the number of people living in the country (PPP). Data stems from IDB Multilateral Investment Fund's Financial Inclusion Report 2014 (Trujillo and Navajas, 2014) and the World Bank Development Research Group's Poverty and Equity Data Base. Data are based on primary household survey data obtained from government statistical agencies and World Bank country departments. In minimizing the potential estimation error due to the difference in size of the countries under examination, we assessed the extent to which the microfinance portfolio, the number of microcredit clients and the number of MFI respond to the size of overall population and to the different segments of the population with income below the 5-, 4- and 2.5-dollar thresholds. Our correlation analysis found positive and significant correlations between all measures (see appendix A), increasing the reliability of our measure. Negative results would have suggested that within country differences were relevant enough to create disproportionate portfolio sizes skewed, for instance, by countries with a big population and high levels of inequality against others perhaps smaller and less unequal.

In measuring social opportunities, we focused on equality in the attainment of education (EDUCATION). In order to do so, we reverse-coded UNPD's inequality in the 
attainment of education, which captures the loss in potential education due to inequality. As previously highlighted, education is a key indicator for social inequality because of its role in assorting individuals into particular labor roles that determines their access to knowledge and other resources (Baker et al., 2005) and has been used in previous studies to represent Sen's social opportunity instrumental freedom (Chliova et al., 2015). Using $0=$ low and $1=$ high, it calculates the percentage difference between the Human Development Index Education Index, which comprises mean years of schooling and expected years of schooling, and the Inequality-adjusted Education Index. We would expect education to be particularly relevant to a microfinance setting because it has been shown to have a strong correlation with microfinance access even though many MFIs continues to offer finance accompanied by training in Latin America (Sanguinetti, 2011). However, given the dominance of individual rather than group lending in the region (MIX Market, 2015), access to education is likely to be particularly important when considering financial inclusion as MFIs adopt tangible proxies in their logic of selection (Baum and Silverman, 2004; Colombo and Grilli, 2010; Macmillan, Zemann, and Subbanarasimha 1987).

Political freedom was captured by looking at Freedom over life choices (CHOICES). It measures the extent to which people are satisfied or dissatisfied with their freedom to make decisions, indicating freedom from oppression, coercion, a right to criticize authority and freedom of expression, and action in their lives. The presence or absence of such a freedom implies not just a particular set of rules and procedures in a particular nation but whether entrepreneurs perceive themselves to be able to voice their needs (such as a need for financial support) and take advantage of opportunities (Sen, 1999). Freedom over life 
choices is assessed on a 0-100 scale that captures the percentage of respondents answering satisfied to the question, "In this country, are you satisfied or dissatisfied with your freedom to choose what you do with your life?" The data stems from Gallup World Poll specifically related to satisfaction pertaining to politics and institutions in Latin America (Arechavala and Espina, 2016). Prior empirical research similarly takes the view that such a definition - inclusive of an individual's civil liberties within their political context - represents an accepted notion of political freedom (Fabro and Aixalá, 2012).

Drawing from Transparency International Data, our measure for Transparency (TRANSPARENCY) assesses the perceived level of public sector corruption based on expert opinion, measured on a scale from 0 (highly corrupt) to 100 (very clean). This is a consistent measure with other studies that have used transparency as a measure of Sen's capabilities (Kimmitt et al., 2016) or simply measured corruption in the context of a nation's institutional quality (e.g. Sobel, 2008). Instead of focusing on the country or territory's position in the index, which is necessarily relative to the other countries and territories in the index, we focused on the actual raw values of transparency.

In terms of outcome measure for financial inclusion (INCLUSION), we focused on the rate of microcredit in the particular context of interest. Using data from IDB Multilateral Investment Fund's Financial Inclusion Report 2014 (Trujillo and Navajas, 2014), we measured financial inclusion by estimating the rate of microcredit clients amongst micro-entrepreneurs. In order to capture financial inclusion within low-income segments, and not across all segments of micro-entrepreneurs, this estimation draws from two sources of relevant data. First, it captures the number of micro-entrepreneurs by looking at the categories Employees/Self-employed and Employers/Employer of 
Household Surveys within low income segments in each country, as reported by World Development Indicators (WDI, 2013). Second, it estimates the number of micro-credit clients by looking at publicly available information or provided directly by financial system authorities, cooperatives regulators in each country, networks or federations of cooperatives, networks of microfinance institutions, and non-regulated credit providers (Trujillo and Navajas, 2014). The fact that this measure draws on data from both regulated (i.e. banks, financial societies and regulated organizations specialized in microfinance) and non-regulated (i.e. cooperatives, NGOs and LLC) institutions enables a more comprehensive and accurate estimation of the number of micro-credit clients within the segment of interest. This is relevant since regulated institutions in the region represent only $33 \%$ of the total number of MFI institutions and $79 \%$ of the microcredit portfolio, serving just 2/3 of Latin-America's microcredit borrowers (Trujillo and Navajas, 2014).

The measure of financial inclusion is developed in accordance with current definitions of inclusion and other empirical insights. Firstly, we follow the definition of George et al. (2012) that distinguishes inclusive processes from outcomes. Process involves actions that promote inclusiveness which are structural barriers that block access to opportunity. In a capabilities framework, this refers to "having the levers of control in one's own hands" (Sen, 1993, p. 522). Drawing further from Sen we also note that use of such economic facilities (i.e. microcredit) - as an instrumental freedom - "directly enhance the capabilities of people" (p.40). Secondly, there is significant empirical evidence supporting the link between financial inclusion and positive entrepreneurial outcomes such as new business creation, income, and business growth (Attanasio et al., 2015; Augsburg et al., 2015; Banerjee and Duflo, 2011; Chliova et al., 2015; Field and Pande, 2008; Shahriar, Schwarz 
and Newman, 2016). In this respect, by focusing on a sub-set of low-income microentrepreneurs using microcredit services allows us to consider the conditions through which financial inclusion occurs because the use of microcredit represents a critical process against structural barriers which typically block opportunity and therefore capabilities.

The method of analysis here is additionally robust as we factor in both the supply of microcredit (MICROFINANCE) in conjunction with demand (INCLUSION) so that the use of microcredit or lack thereof cannot be solely explained by the presence or absence of MFIs willing to serve micro-entrepreneurs. In addition, we recognise the presence of informal lending mechanisms in such contexts as a potential funding source for entrepreneurs. However, in Latin America, evidence suggests that informal credit accounts for $21 \%$ of lending but the vast majority of this is for "consumption" loans (i.e. loans for consumer purchases rather than an entrepreneurial investment). Given the sole focus of micro-entrepreneurs in this study, this suggests that informal use of capital is less relevant to this population and for financial inclusion (Sanguinetti, 2011). Where some informal use of microcredit by micro-entrepreneurs may be present, this is captured within our measure of MICROFINANCE which includes data from the regulated (79\%) and nonregulated microfinance sector $(21 \%)$.

\section{Calibration and data analysis}

A set-theoretic method is an approach to analysing social phenomena in which the data consist of set membership scores, relations between social phenomena are modelled in terms of set relations, and these set relations are interpreted in terms of sufficiency and necessity, as well as combinations of causes that can be derived from them (Schneider and 
Wagemann 2012). As a set-theoretic method, this analytical tool is capable of handling the increased complexity of multilevel analysis by incorporating it as a series of set memberships within the standard configurational comparative approach (Lacey and Fiss 2009).

Set relations, however, can only be modelled and assessed if variables are reconsidered as sets of things and data is comparable. Given the diversity of measures and scales, we used fs/QCA's calibration procedure to transform the variable raw scores into set measures, this by rescaling the original measure into scores ranging from 0.0 to 1.0 (Ragin 2008b). This permits to specify inclusion and exclusion of the sets of interest (e.g. set of countries with strong equality in the attainment of education) and subsequently to systematically compare cases based on how causal conditions combine to produce the outcome under examination. In this study, calibration seeks to create fuzzy-set scores that represent strong membership in causal conditions and the outcome. In order to do so, we divided the calibration procedure into two parts. We first draw on theory and distribution of scores to define thresholds for full inclusion, full exclusion and maximum ambiguity, to then squareroot the membership scores and obtain higher inclusion in the relevant sets. Table 1 presents the calibration criteria for all five measures, and Calibration Table 2 depicts the calibration scores for the 19 cases. Raw data for all 19 countries and descriptive and correlations for our calibrated measures are available in Appendices B and C respectively.

Table 1 here

Table 2 here 
Calibration enables the construction of a truth table, which lists all different logically possible combinations of causal conditions along with the cases conforming to each combination. In order to reduce the truth table to simplified combinations, two thresholds need to be defined. The frequency threshold specifies the minimum amount of cases to be considered in the analysis. Setting a frequency threshold of one observation is acceptable when the aim is to build theory from a relatively small sample (Ragin 2006; Crilly 2011). The consistency threshold, on the other hand, defines the minimum acceptable level to which a combination of causal conditions is reliably associated with the each of the outcomes. A consistency threshold of $>0.75$ is recommended. Table 3 shows the truth table with the resulting 9 configurations and 19 cases that are relevant for the outcome. 11 cases exceeded the lowest acceptable consistency, set at 0.775 , and 8 cases are below the consistency cut-off line.

Table 3 here

\section{Results}

In reducing the truth table rows to more simplified combinations of conditions, fs/QCA applies a Boolean algorithm based on a counterfactual analysis of causal conditions and logical minimization. This procedure yields a solution table (Table 4) comprising four simplified combinations of conditions, which can be understood as different solution paths (Ragin, 2008a) or in this case configurations of instrumental freedoms leading to Financial Inclusion amongst low-income micro-entrepreneurs. 
Table 4 here

Solution paths are evaluated in terms of consistency and coverage. Set-theoretic consistency assesses the degree to which the cases sharing a given condition or combination of conditions agree in displaying the outcome under examination. It is estimated by dividing the number of cases that are present in a given configuration of conditions and exhibit the outcome by the number of cases that are present in the same configuration but do not exhibit the outcome (Fiss 2011). Set-theoretic coverage assesses the degree to which a causal combination accounts for instances of an outcome (Ragin 2006), which highlights the empirical power of a particular solution term. If multiple configurations are sufficient for the outcome, raw and unique coverage scores provide assessments of their empirical relevance (Greckhamer 2011). These set-theoretic measures of fit are descriptive, not inferential, and were created to explore cross-case evidence in a configurational manner.

Results confirm that the set relation between configurations of conditions and the outcome is highly consistent, with individual results above .81, and an overall consistency of .78. The total coverage of the solution is .73 indicating that most of the outcome is explained by the causal paths and that the solution as a whole is empirically relevant. The solution table distinguishes core and peripheral conditions, which is based on how causal components are causally connected to the outcome. In any causal recipe there are decisive or core causal ingredients that distinguish configurations, and complementary ingredients that only make sense as contributing factors (Grandori and Furnari 2008). Large and small 
circles represent core and peripheral conditions, respectively. Black circles are used to indicate presence of condition whereas white circles with an $\mathrm{X}$ are used to indicate absence of the condition. No circle indicates that the condition is irrelevant for explaining the outcome under examination. Presence of MICROFINANCE and TRANSPARENCY and absence of EDUCATION and CHOICES are core conditions, exhibiting strong causal relationship with INCLUSION.

Findings indicate that strong financial inclusion in developing contexts does not depend on a single instrumental freedom (or combination thereof), but emerges from four sufficient configurations of causal conditions. Although they differ in terms of empirical relevance, the results point out a situation of true multi-conjunctural causality. We summarise the four combinations in Table 5.

Table 5 here

Solution 1: Microfinance, Political Freedom and Transparency

Solution 1 presents a causal combination of conditions where presence of economic freedom (MICROFINANCE) is a core condition accompanied by presence of political freedom (CHOICES) and TRANSPARENCY. Despite its importance in producing the outcome, microfinance is not sufficient for financial inclusion. In cases such as Chile $(0.6,0.97)$ and Colombia $(0.54,0.61)$, provision of microfinance is generally complemented by freedom over life choices and low perceived level of public sector corruption. In such countries, individuals are free to start and grow their own businesses within institutional neo-liberal contexts exhibiting high government capacity, yet low government interference. 
This allows for an understanding of the role of institutional instrumental freedoms and how they relate to financial inclusivity in their holistic sense (Sen 1999). In the first solution, we identify that financial inclusivity - the rate of microfinance amongst the entrepreneurial poor - to be driven by the presence of economic facilities (microfinance), political freedom and high transparency (low corruption). This is perhaps the solution which is most consistent with current thinking as we would expect more use of microfinance where there is provision but also willing use of external financial resources in the absence of harassment associated with trading (Fadahunsi and Rosa, 2002).

\section{Solution 2: Transparency, Political Freedoms and absence of Education}

In solution 2, presence of TRANSPARENCY and absence of EDUCATION are core conditions, however complementary freedoms are needed to produce the outcome. In this solution term, the presence of CHOICES reinforces the central features of the core conditions. The solution suggests that in countries such as Mexico $(0.501,0.88)$ and El Salvador $(0.51,0.501)$ strong financial inclusion results from the lack of social opportunities, but presence of political freedom and transparency. Most notably, microfinance provision is relatively high in both countries but not relevant for financial inclusion, in other words, in contexts with presence of transparency and political freedoms and absence of social opportunities, financial inclusion emerges either way with or without microfinance provision. Interestingly, corruption levels in these countries are normally recognized as relatively high compared to the rest of the region, which may contradict common knowledge and hence the relevance of this solution term. We argue that in the setting of interest, corruption is part of the business costs - a 'corruption norm' (Budak and 
Rajh, 2014) - moving micro entrepreneurship outside of the system towards informality, which facilitates business development due to less harassment with trading.

Solution 3: Microfinance, Political Freedom and lack of Education

Solution 3 shows a causal combination of conditions where presence of economic freedom and protective security (MICROFINANCE), as core condition, is accompanied by absence of social opportunities (EDUCATION) and presence of political freedom (CHOICES). In countries such as Bolivia $(0.81,0.94)$ and Ecuador $(0.55,0.72)$, microfinance provision is high, which seems to be the primary trigger of high rates of microcredit customers among micro entrepreneurs, as these countries show low education equality and the importance of freedom over life choices is merely peripheral. In these contexts, micro entrepreneurs are scattered through the country in remote areas, not relying on central government support, which normally lacks capacity, turning (perception of) transparency into an irrelevant condition. Micro entrepreneurs are more autonomous and work in conjunction with the local, mission-driven MFIs, since they provide financial resources and support in a context with lack of social opportunities. This suggests that political freedom is needed for economic freedom to flourish and is therefore a critical ingredient for financial inclusivity in contexts where microfinance provision is present or absent.

Solution 4: Absence of all instrumental freedoms

Finally, solution 4 presents a counterintuitive solution with only one observation, suggesting that high rates of microcredit amongst micro-entrepreneurs can occur even under odd conditions, in contexts where the lack of all instrumental freedoms can nevertheless lead to financial inclusion amongst micro-entrepreneurs. These contexts are 
historically characterized by authoritarian government and/or military regimes, where there is no room for MFIs, being replaced with informal lending. Education is unequal, yet such contexts require a closer examination since its effect is not contingent to coverage but rather to the content of the education. Interestingly, this case only enables the emergence of that possible combination (i.e. lack of all instrumental freedoms), which can only be fundable at this stage through counterfactual analysis. This means that such a combination of conditions is highly plausible and most likely will lead to strong financial inclusion, but this still needs to be found in the empirical world. The causal inference made in solution 4 is logically possible only in light of the available evidence and alternative causal paths. The case of Honduras, with set membership scores of 0.55 in the solution term and 0.16 in the outcome, sheds light on a combination of instrumental freedoms that is highly likely to lead to financial inclusion, despite the lack of it shown by this particular case. An important benefit of considering outliers and counterintuitive cases is the reduction of expectation bias, which means that regardless of the presence of certain expectations, no causal path has been downgraded, disbelieved, or discarded.

These four solutions are theoretical statements, representing causal conjuctures leading to financial inclusion. They can also be analyzed and interpreted horizontally, which entails observing the individual effect of the most salient conditions in terms of how necessary or sufficient are these conditions by themselves to produce financial inclusion. In order to do so, we conducted a confirmatory necessity analysis (Table 6), which once observed alongside the configurational analysis (Table 4), enables a richer set of findings. Our analyses found no single instrumental freedom necessary for financial inclusion. In other words, no condition must be in place to create a situation where the outcome can 
occur. In spite of the empirical relevance of economic freedom (microfinance) and the consistency of political freedom, none of them constitute a necessary condition for strong financial inclusion amongst micro-entrepreneurs, as most literature assumes. We observe that microfinance is predominant across Latin America and the Caribbean, but its effect on financial inclusion is highly inconsistent. On the other hand, political freedom is not omnipresent across region, but where political freedom is strong micro entrepreneurs appear to flourish alongside MFIs, showing therefore a consistent effect on producing financial inclusion. This leads us to argue that financial inclusion is possible without economic freedom (microfinance) but mostly unfeasible without political freedom.

Table 6 here

Low Financial Inclusion amongst micro-entrepreneurs

Our analyses also found eight countries with weak financial inclusion and inconsistent combinations of instrumental freedoms. In analyzing how conditions combine and relate to the outcome of interest within this group, we observed three distinct sets of countries and one outlier. The first group includes Argentina (education -> inclusion 0.05) and Venezuela (education -> inclusion 0.05). Both countries show similar political institutions developed over the last two decades, which have prioritized a large welfare state capable of providing strong equality of education, yet unsustainable due to their underperforming economic systems. The level of financial inclusion however is extremely low and can be explained by the lack of political and economic freedoms (microfinance) and transparency. Social opportunities are not sufficient in a highly corrupt context lacking freedom over life 
choices. In addition, both countries exhibit a shallow financial sector, high interest rates $(>50 \%)$ within a context with extremely low microfinance provision $(<2 \%)$. Three countries from the Caribbean also exhibit similar conditions leading to relatively low financial inclusion: Dominican Republic (choices $->0.34$ ), Nicaragua (choices $->0.45$ ), Guatemala (choices -> 0.42). Similarly, Panama and Paraguay exhibit high levels of social opportunities and political freedom, yet dissimilar levels of financial inclusion.

Perhaps one of the most interesting counterintuitive cases in the sample is Uruguay, as it shows robust instrumental freedoms (social opportunities, political freedom and transparency), yet low levels of microfinance among micro entrepreneurs (membership score of 0.12). We suspect that its unique political and economic system (welfare state; community safety nets; and informal sources) has led to create a situation where the lack of financial inclusion, as measured, can be explained by the fact that micro lending for micro entrepreneurs is already embedded in the system.

\section{Contribution, Future Research and Limitations}

In this paper we asked, how do the interrelated nature of instrumental freedoms combine to engender financial inclusivity amongst micro-entrepreneurs? This places the focus of our inquiry on the interrelationship between instrumental freedoms rather than on the individual factors contained in the overall notion of freedom, as the associated causal relationships are not discrete but rather conjunctural in nature. To examine these relationships, we need to go beyond the traditional decomposability logic used in linear modeling, where the outcome of interest is explained as the sum of net effects of the individual predictors (Ragin and Fiss 2010). 
Acknowledging the need for a different analytical approach, we draw from the seminal work of Sen $(1999 ; 2005)$ to examine the causal configurations associated with financial inclusion amongst low-income micro-entrepreneurs in Latin America. Our findings indicate that financial inclusion in developing contexts does not depend on one single instrumental freedom. In particular, we identify that the presence of microfinance (economic freedom) does not necessarily produce financial inclusion but that it is mostly not feasible without the presence of political freedom. Our analysis indicates that financial inclusion stems from four sufficient configurations of causal conditions. As such, we make a number of contributions to the literature that we will outline in the following.

Firstly, we contribute to the existing view within the literature concerning the role of the institutional environment in microfinance. We argued that the current view in the literature suggests that a particular set of institutional conditions may produce particular development outcomes neglecting their view as freedoms within institutional settings moving away from the idea of 'transcendental institutionalism', as outlined by Sen (2009). Although institutions and freedoms are naturally intertwined, instrumental freedoms are a more relevant focus of analysis because they reveal fully their complex interrelations that actually contribute to financial inclusion.

This is highlighted in the results through Solution 2 which demonstrates the presence of transparency guarantees, lack of social opportunities (education) and political freedoms (freedom over life choices) that leads to financial inclusion. This is despite an objective sense that the countries in this solution (see Appendix D) would typically be viewed as having high levels of corruption yet it has no bearing on the outcome. In freedom terms, we suggest that corruption can actually be viewed as a business norm and part of the day- 
to-day entrepreneurial landscape, having a limited perceived bearing on their willingness to invest loans and trade i.e. financial inclusion.

By shifting the focus onto instrumental freedoms as a consequence of the institutional context, we get a more accurate reflection of the moulding effect of the context. This reinforces the idea that a search for a 'perfect' set of developed institutional conditions that lead to financial inclusion amongst micro-entrepreneurs is unlikely - the transcendental argument. Again, this is emphasized in Solution 2 which shows that financial inclusion emerges either way with or without "microfinance provision" (Newman et al., 2013). This indicates that in these contexts (see Appendix D) the lines between 'mission-driven' microfinance and the commercial banking sector are blurred to the extent that the financial system as a whole is now more inclusive with commercial banks delivering products and services to the entrepreneurial poor; something hinted at by Khavul et al. (2013). In addition, this seems to rely on the absence of corruption suggesting that integrating the entrepreneurial poor into the established financial system relies on the instrumental freedom of transparency.

Secondly, we contribute towards a more institutionally complex view of microfinance activity. We argued that previous empirical efforts in this area lack analytical power because they rely on joint interactions between a set of variables that loses the holistic casebased configuration of instrumental freedoms and complexity of how they interact with each other (Greenwood, Raynard, Kodeih, Micelotta, and Lounsbury, 2011; Munoz and Kibler, 2016). In our results, this is highlighted by the four causal conjuctures we present that offer the most appropriate application of the interrelatedness of instrumental freedoms in Sen's $(1999 ; 2005)$ capability theory. This emphasizes the "remarkable empirical 
connection that links freedoms of different kinds with one another" (1999, p.11). We present four solutions that each provide individual paths to financial inclusion. Despite the heterogeneity across the solutions, we see one consistent theme across the first three; the empirical connection between political freedom as a peripheral condition for financial inclusivity. However, despite its supportive role (due to its low coverage across the region) it is highly consistent across those countries with strong financial inclusivity, suggesting a situation of robust quasi-necessity, which means that if that condition is removed, financial inclusivity will most likely disappear. This is supported by the negate analysis of the outcome ( outcome). Here we can observe a consistency in cases where there are a lack of political freedoms and very low financial inclusion. Typically, political freedom (freedom from oppression, coercion, right to criticize authority etc.) has an empirical link with economic security in the sense that more politically inclusive societies tend to be more open, stable and prosperous (Acemoglu and Robinson, 2012).

If we are, on the contrary, to focus on aggregated net effect, we would be forced to assume that all freedoms are necessary for financial inclusion in entrepreneurship, when in real-world social science we know that the importance of a given institutional factor is context and temporal sensitive or be altogether peripheral in nature (Munoz and Dimov, 2015). Our analysis indeed assumes that the instrumental freedoms under examination are neither necessary nor sufficient for financial inclusion, and that they will only make sense when considered together. Microfinance provision is particularly interesting in this regard. While it has been seen as central for the emergence of "inclusive" entrepreneurship, we have observed that financial inclusion seems actually possible without economic freedom (microfinance provision), but it seems to be unfeasible without political freedom. From an 
MFI perspective, this suggests that lenders require a workable and open political context to operate in. From a borrower's perspective, this suggests that micro-entrepreneurs may also require politically open and inclusive contexts as an aspect of the 'appropriability regime', where they can capture sufficient value from business opportunities - political and entrepreneurial agency appear intertwined (Baker et al., 2005).

Finally, our work makes an important contribution to literature by retaining and discussing the role of counterintuitive solutions and cases, which when seen and analyzed by means of traditional linear models are treated as errors and thus dropped from the analysis. Counterintuitive solutions represent theoretical statements only discoverable by counterfactual analysis and logical testing. Despite its low empirical representation in our small sample of countries, Solution 4 is highly likely to emerge either in a larger sample or in the future, constituting a powerful tool to predict financial inclusivity within otherwise odd contexts. This is one of the most salient benefits of fs/QCA, and we hope it will inspire future work in the area.

Relations between variables in configurational comparative studies are theoretically informed (Ragin 2008), where the direction of causality for individual factors is known, yet the way they work in combination in a particular empirical setting is hidden. The idea of fs/QCA being a method for devising how different ingredients can be combined in alternative causal recipes for baking a "cake" illustrates this understanding of causality. Nevertheless, in any case where reverse causality can be seen as credibility risk, we are obliged to corroborate that the direction inferred ex-ante holds when tested. This is particularly relevant when a condition and an outcome share certain aspects, as in this case of microcredit. In our study, microcredit is both present within a condition portraying size 
of microcredit portfolio (offer) and within the outcome as a component of the measure that enable us to estimate financial inclusion, as the rate of microcredit clients among microentrepreneurs (demand). In dissipating such a concern, we run two tests: a subset/superset analysis to evaluate whether our measure of financial inclusion is a subset or superset of microcredit provision, and an alternative fs/QCA switching the outcome and causal conditions. Both tests confirm the robustness of the results.

Aside from our contribution, there are limitations to our study that also need to be considered. Firstly, we discuss financial inclusion as an important process for overcoming structural barriers given the clear link in extant research between microcredit and positive entrepreneurial outcomes. Although financial inclusion is clearly important for stimulating entrepreneurship, research has found a less clear link between this and wider well-being outcomes. Given that entrepreneurs operate in complex systems, such a complexity perspective (as adopted in this paper through our methodology) raises significant questions about the degree to which an intervention (such as bringing someone into the formal financial system) can actually be attributed to the intervention itself (Byrne and Callaghan 2014). This kind of investigation that embraces real world complexity through fs/QCA methodology and microfinance's broader relationship with well-being outcomes would be a fruitful avenue for future research.

Secondly, we focus our analysis in Latin America and the Caribbean. To the extent that this only represents one broad contextual setting for the research - but sufficiently homogenous and with maximum heterogeneity to perform a fs/QCA - our extrapolation of the results to different settings should be made with caution. Second, our analysis is restricted to the total amount of the microcredit portfolio (microfinance provision) across 
each individual country including a wide range of sources, yet we can say much about the individual, and presumably distinct effect of the different types of MFIs. These are wide and varied in terms of their motives, activities and products which can provide some more insightful detail into the country level data concerning economic freedoms. We strongly encourage future research to go under the hood of MFIs to observe the varying effect of the different types of organizations on financial inclusivity such as non-formal and nonregulated micro-lending.

\section{Conclusion}

In this paper, we asked, how do the interrelated nature of instrumental freedoms combine to engender financial inclusivity amongst micro-entrepreneurs? Drawing from Sen's capabilities perspective, we argued for a need to focus on instrumental freedoms as a function of their institutional context. This approach requires embracing the causal complexity associated with financial inclusion. By conducting an fs/QCA of Latin American and Caribbean countries, our results highlight four causal conjuctures as theoretical statements that depict the distinctive paths for financial inclusion. In viewing this as a complex causal process, we are able to demonstrate that no single instrumental freedom is necessary for financial inclusion and that it requires more than just the provision of microfinance.

Uncovering the antecedents of financial inclusion is certainly central to alleviate some of today's most pressing problems. Provision of microfinance has been assumed to play a pivotal role towards this end in that it enables economic activity of microentrepreneurs. While relevant, our configurational examination demonstrates that, by itself, 
it is insufficient to engender financial inclusion amongst this population, requiring additional enabling factors which we observed through the lens of freedoms, with political freedoms playing a particularly strong role. Most notably, we discovered that this is not a one-size-fits all recipe because financial inclusion can occur under alternative and even odd combinations of freedoms. Four possible configurations emerged from our data, representing alternative theoretical and policy statements that robustly deal with and inform the empirical complexity at the intersection of micro-entrepreneurship, microfinance and financial inclusion. 


\section{References}

Acemoglu, D., R, J, A. (2012). Why Nations Fail: The Origins of Power, Prosperity and Poverty: Crown Publishers.

Acs, Z., Virgill, Nicola. (2010). Entrepreneurship in Developing Countries. In Z. Acs, Audretsch, David (Ed.), Handbook of Entrepreneurship Research. New York: Springer.

Anand, V., Ashforth, B. E., and Joshi, M. (2004). Business as usual: The acceptance and perpetuation of corruption in organizations. The Academy of Management Executive, 18(2), 39-53.

Anand, P., Hunter, G., Carter, I., Dowding, K., Guala, F., and Van Hees, M. (2009). The Development of Capability Indicators. Journal of Human Development and Capabilities, 10(1), 125-152.

Alkire, S. (2005). Why the Capability Approach? Journal of Human Development, 6(1), 115-135.

Ansari, S., Munir, K., and Gregg, T. (2012). Impact at the 'Bottom of the Pyramid': The Role of Social Capital in Capability Development and Community Empowerment. Journal of Management Studies, 49(4), 813-842.

Armendariz, B., Morduch, J. (2000). Microfinace Beyond Group Lending. Economics of Transition, 8(2), 401-420.

Attanasio, O., Augsburg, B., De Haas, R., Fitzsimons, E., and Harmgart, H. (2015). The impacts of microfinance: Evidence from joint-liability lending in Mongolia. American Economic Journal: Applied Economics, 7(1), 90-122.

Augsburg, B., De Haas, R., Harmgart, H., and Meghir, C. (2015). The impacts of microcredit: Evidence from Bosnia and Herzegovina. American Economic Journal: Applied Economics, 7(1), 183-203.

Baker, T., Gedajlovic, E., and Lubatkin, M. (2005). A framework for comparing entrepreneurship processes across nations. Journal of International Business Studies, 36(5), 492-504.

Banerjee, A. (2007). The Economic Lives of the Poor. Journal of economic Perspectives, 21(1), 141-167.

Baum, J. A., and Silverman, B. S. (2004). Picking winners or building them? Alliance, intellectual, and human capital as selection criteria in venture financing and performance of biotechnology startups. Journal of business venturing, 19(3), 411-436.

Baumol, W. (1990). Entrepreneurship: Productive, Unproductive and Destructive. Journal of Political Economy, 98(5), 893-921.

Beck, T., and Demirgüç-Kunt, A. (2008). Access to Finance: An Unfinished Agenda. The World Bank Economic Review, 22(3), 383-396.

Berk, R., 1983. An introduction to sample selection bias in sociological data. American Sociological Review, 48(3), 386-398. 
Berkowitz, D., and DeJong, D. N. (2005). Entrepreneurship and Post-socialist Growth. Oxford Bulletin of Economics and Statistics, 67(1), 25-46.

Berthelemy, J. C., and Varoudakis, A. (1996). Economic Growth, Convergence Clubs, and the Role of Financial Development. Oxford Economic Papers, 48(2), 300-328.

Bianchi, M. (2010). Credit constraints, entrepreneurial talent, and economic development. Small Business Economics, 34(1), 93-104.

Bradley, S. W., McMullen, J. S., Artz, K., and Simiyu, E. M. (2012). Capital Is Not Enough: Innovation in Developing Economies. Journal of Management Studies, 49(4), 684-717.

Bruns, V., Holland, D. V., Shepherd, D. A., and Wiklund, J. (2008). The role of human capital in loan officers' decision policies. Entrepreneurship Theory and Practice, 32(3), 485-506.

Bruton, G. D., Khavul, S., \& Chavez, H. (2011). Microlending in emerging economies: Building a new line of inquiry from the ground up. Journal of International Business Studies, 42(5), 718-739.

Buchmann, C., and Hannum, E. (2001). Education and Stratification in Developing Countries: A Review of Theories and Research. Annual Review of Sociology, 27(1), 77102.

Budak, J., and Rajh, E. (2014). Corruption as an obstacle for doing business in the Western Balkans: A business sector perspective. International Small Business Journal, Vol. 32(2) 140-157.

Canales, R. (2014). Weaving Straw into Gold: Managing Organizational Tensions Between Standardization and Flexibility in Microfinance. Organization Science, 25(1), 128.

Chliova, M., Brinckmann, J., and Rosenbusch, N. (2015). Is microcredit a blessing for the poor? A meta-analysis examining development outcomes and contextual considerations. Journal of Business Venturing, 30(3), 467-487.

Colombo, M. G., and Grilli, L. (2010). On growth drivers of high-tech start-ups: Exploring the role of founders' human capital and venture capital. Journal of Business Venturing, 25(6), 610-626.

Crilly, D. 2011. Predicting stakeholder orientation in multinational enterprise: A mid-range theory. Journal of International Business Studies, 42, 694-717

Demirgüç-Kunt, A., and Klapper, L. F. (2012). Measuring financial inclusion: The global findex database. World Bank Policy Research Working Paper, (6025).

Dollar, D., and Kraay, A. (2002). Growth is Good for the Poor. Journal of Economic Growth, 7(3), 195-225.

Eade, D. (2007). Capacity building: who builds whose capacity? .Development in practice, 17(4-5), 630-639.

Easterly, W. (2001). The Elusive Quest for Growth: Economists' Adventures and Misadventures in the Tropics. Massachusetts: MIT Press. 
Eid, F. (2005). Institutional complementarities and entrepreneurial finance in emerging markets: Evidence from the Middle East and North Africa. Venture Capital, 7(4), 319-341.

Fadahunsi, A., and Rosa, P. (2002). Entrepreneurship and Illegality: Insights from the Nigerian cross-border Trade. Journal of Business Venturing, 17(5), 397-429.

Ferdousi, F. (2015). Impact of microfinance on sustainable entrepreneurship development. Development Studies Research, 2(1), 51-63.

Field, E., and Pande, R. (2008). Repayment frequency and default in microfinance: evidence from India. Journal of the European Economic Association, 6(2-3), 501-509.

Field, E., Pande, R., Papp, J., and Rigol, N. (2013). Does the classic microfinance model discourage entrepreneurship among the poor? Experimental evidence from India. The American Economic Review, 103(6), 2196-2226.

Fiss, P. 2011. Building Better Causal Theories: A Fuzzy Set Approach to Typologies in Organization Research. Academy of Management Journal, 54(2), 393-420

George, G., McGahan, A. M., and Prabhu, J. (2012). Innovation for Inclusive Growth: Towards a Theoretical Framework and a Research Agenda. Journal of Management Studies, 49(4), 661-683.

Greenwood, R., Raynard, M., Kodeih, F., Micelotta, E. R., and Lounsbury, M. (2011). Institutional Complexity and Organizational Responses. The Academy of Management Annals, 5(1), 317-371.

Gonzalez-Vega, C. 1994. Stages in Evolution of Thought on Rural Finance: A Vision from the Ohio State University. Occasional Paper No. 2134, Rural Finance Program, Ohio State University

Grandori, A. and Furnari, S., 2008. A Chemistry of Organization: Combinatory Analysis and Design. Organization Studies, 29(3), 459-485.

Greenwood, R., Raynard, M., Kodeih, F., Micelotta, E., and Lounsbury, M. 2011. Institutional complexity and organizational responses. The Academy of Management Annals, 5(1), 317-371.

Greckhamer, T., 2011. Cross-cultural Differences in Compensation Level and Inequality across Occupations: A Set-theoretic Analysis. Organization Studies, 32(1), 85-115

Gries, T., and Naudé, W. (2011). Entrepreneurship and human development: A capability approach. Journal of Public Economics, 95(3-4), 216-224.

Gupta, S., Davoodi, H., and Alonso-Terme, R. (2002). Does corruption affect income inequality and poverty? Economics of Governance, 3(1), 23-45.

Helms, B. (2006). Access for All: Building Inclusive Financial Systems. Washington: World Bank.

Hoffman, J., A. (1999). Institutional Evolution and Change: Environmentalism and the U.S. Chemical Industry. Academy of Management Journal, 42(4), 351-371.

Honohan, P. (2007). Making Finance Work for Africa. Retrieved from http://NCL.eblib.com/patron/FullRecord.aspx?p=459520 
Khavul, S., Bruton, G. D., and Wood, E. (2009). Informal family business in Africa. Entrepreneurship Theory and Practice, 33(6), 1219-1238.

Khavul, S., Chavez, H., and Bruton, G. D. (2013). When institutional change outruns the change agent: The contested terrain of entrepreneurial microfinance for those in poverty. Journal of Business Venturing, 28(1), 30-50.

Kimmitt, J., Scarlata, M., and Dimov, D. (2016). An empirical investigation of the interplay between microcredit, institutional context, and entrepreneurial capabilities. Venture Capital, 1-20.

Kumar K, N. (2012). Dynamic Incentives in Microfinance Group Lending: An Empirical Analysis of Progressive Lending Mechanism. SAGE Open, 2(2).

Lacey, R. and Fiss, P. 2009. Comparative Organizational Analysis across multiple levels: a set-theoretic approach. In B. King, T. Felin, and D. Whetten, [eds.] Studying Differences Between Organizations: Comparative Approaches to Organizational Research, 1-39. Volume 26. Bingley: Emerald/JAI.

Leiberson, S. 1991. Small N's and big conclusions: an examination of the reasoning in comparative studies based on a small number of cases. Social Forces, 70(2), 307-320

Levine, R. (1998). The Legal Environment, Banks and Long-Run Economic Growth. Journal of Money, Credit, and Banking, 30(3), 596-613.

MacMillan, I., Zemann, L., Narasimha, P. N. S. Spring, (1987) Effectiveness of criteria used by venture capitalists in the venture screening process. Journal of Business Venturing. 2(1):123-138.

Mair, J., Marti, I. (2009). Entrepreneurship in and around institutional voids: A Case Study from Bangladesh. Journal of Business Venturing, 24, 419-435.

Martinelli, A. (Ed.) (1994). Entrepreneurship and Management. New Jersey: Princeton University Press.

Mcmillan, J., Woodruff, C. (2002). The Central Role of Entrepreneurs in Transition Economies. Journal of economic Perspectives, 16(3), 153-170.

McMullen, J. S. (2011). Delineating the Domain of Development Entrepreneurship: A Market-Based Approach to Facilitating Inclusive Economic Growth. Entrepreneurship Theory and Practice, 35(1), 185-193.

Minniti, M., and Lévesque, M. (2010). Entrepreneurial types and economic growth. Journal of Business Venturing, 25(3), 305-314.

Microfinance Information Exchange. (2015) Microfinance Market and Trends in Latin America and the Caribbean (Accessed $23^{\text {rd }}$ November, 2016)

Morduch, J. (1999). The Microfinance Promise. Journal of Economic Literature, 37(4), 1569-1614.

Morduch, J. (2000). The Microfinance Schism. World Development, 28(4), 617-629.

Munoz, P. and Dimov, D., (2015). The Call of the Whole in Understanding the Development of Sustainable Ventures. Journal of Business Venturing, 30(4), 632-654. 
Munoz, P. and Kibler, E., (2016). Institutional complexity and social entrepreneurship: A fuzzy-set approach. Journal of business research, 69(4), 1314-1318.

Newman, A., Schwarz, S., and Borgia, D. (2013). How does microfinance enhance entrepreneurial outcomes in emerging economies? The mediating mechanisms of psychological and social capital. International Small Business Journal. 32(2) 158-179

North, D. C. (1987). Institutions, Transactions Costs and Economic Growth. Economic Inquiry, 25(3), 419-428.

North, D. C. (1990). Institutions, Institutional Change and Economic Performance. Cambridge: Cambridge University Press.

Nussbaum, M. (2000). Women and Human Development. Cambridge: Cambridge University Press.

Ragin, C., 1999. Using qualitative comparative analysis to study causal complexity. Health Services Research, 34(5-2), 1225-1239.

Ragin, C., (2006). Set Relations in Social Research: Evaluating Their Consistency and Coverage. Political Analysis, 14(3), 291-310.

Ragin, C. (2008a). Qualitative Comparative Analysis Using Fuzzy Sets (fsQCA).' In Rihoux, B. and Ragin, C. [eds.] Configurational Comparative Analysis. Thousand Oaks, $\mathrm{CA}$ and London: Sage Publications

Ragin, C. (2008b). Redesigning social inquiry: fuzzy sets and beyond. Chicago/London: University of Chicago Press.

Ragin, C. (2008c). Calibration Versus Measurement. In Collier, D., Brady, H., and BoxSteffensmeier, J. [eds.] Oxford Handbook of Political Methodology, 174-198, Oxford: Oxford University Press.

Ragin, C. and Fiss, P., 2010. Net effects versus configurations: an empirical demonstration. In C. Ragin, Redesigning Social Inquiry Fuzzy Sets and Beyond. University of Chicago Press, pp. 190-213.

Ravlin, E. C., and Thomas, D. C. (2005). Status and Stratification Processes in Organizational Life. Journal of Management, 31(6), 966-987.

Rihoux, B. and Ragin, C. (2008) Configurational Comparative Analysis. Thousand Oaks, $\mathrm{CA}$ and London: Sage Publications.

Robinson, J., Blockson, L., and Robinson, S. (2007). Exploring Stratification and Entrepreneurship: African American Women Entrepreneurs Redefine Success in Growth Ventures. The ANNALS of the American Academy of Political and Social Science, 613(1), 131-154.

Ronstadt, R. (1988). The Corridor Principle. Journal of Business Venturing, 3(1), 31-40.

Roth, K., and Kostova, T. (2003). Organizational coping with institutional upheaval in transition economies. Journal of World Business, 38(4), 314-330.

Sanguinetti, P. (Ed) (2011). Financial services for development: promoting access in Latin America. Economics and Development Report Series. CAF publishers. Colombia 
Sautet, F. (2013). Local and Systemic Entrepreneurship: Solving the Puzzle of Entrepreneurship and Economic Development. Entrepreneurship Theory and Practice, 37(2), 387-402.

Schneider, C. and Wagemann, C. 2012. Set-Theoretic Methods for the Social Sciences: A Guide to Qualitative Comparative Analysis. Cambridge: Cambridge University Press.

Schumpeter, J. (1934). Capitalism, Socialism and Democracy. New York: Harper and Row.

Scott, W. R. (2001). Institutions and organizations. Sage.

Scully, G. W. (1988). The Institutional Framework and Economic Development. Journal of Political Economy, 96(3), 652-662.

Seidman, G. (1999). Is South Africa Different? Sociological Comparisons and Theoretical Contributions from the Land of Apartheid. Annual Review of Sociology, 25(1), 419-440.

Sen, A. (1987). The Standard of Living. Cambridge: Cambridge University Press.

Sen, A. (1999). Development as Freedom. Oxford: Oxford University Press.

Sen, A. (2005). Human Rights and Capabilities. Journal of Human Development, 6(2), 151-166

Sen, A. (2009). The Idea of Justice. Allen Lane and Harvard University Press.

Shahriar, A. Z. M., Schwarz, S., and Newman, A. (2016). Profit orientation of microfinance institutions and provision of financial capital to business start-ups. International Small Business Journal, Vol. 34(4) 532-552.

Shleifer, A., Vishny, R, W. (1997). A Survey of Corporate Governance. Journal of Finance (2), 737-783.

Silva, A. C., and Chávez, G. A. (2015). Microfinance, country governance, and the global financial crisis. Venture Capital, 1-23.

Sobel, R. S. 2008. "Testing Baumol: Institutional Quality and the Productivty of Entrepreneurship.” Journal of Business Venturing 23 (6): 641-655

Smallbone, D., Welter, F., and Ateljevic, J. (2013). Entrepreneurship in emerging market economies: Contemporary issues and perspectives. International Small Business Journal.

Takyi-Asiedu, S. (1993). Some socio-cultural factors retarding entrepreneurial activity in sub-Saharan Africa. Journal of Business Venturing, 8(2), 91-98.

Arechavala, N, S, and Zarzosa Espina P, Z. (2016) Quality of Life in Latin America: A Proposal for a Synthetic Indicator in Tonon, G. (Ed.). Indicators of Quality of Life in Latin America (Vol. 62). Springer.

Trujillo, V and Navajas, S (2014) Financial Inclusion in Latin America and the Caribbean: Data and Trends. Multilateral Investment Fund. IDB Group.

Venkataraman, S. (1997). The Distinctive Domain of Entrepreneurship Research. Advances in Entrepreneurship, Firm Emergence and Growth, 3, 119-138. 
Webb, J. W., Kistruck, G. M., Ireland, R. D., and Ketchen, J. D. J. (2010). The Entrepreneurship Process in Base of the Pyramid Markets: The Case of Multinational Enterprise/Nongovernment Organization Alliances. Entrepreneurship Theory and Practice, 34(3), 555-581.

Welter, F. (2011). Contextualizing entrepreneurship-conceptual challenges and ways forward. Entrepreneurship Theory and Practice, 35(1), 165-184.

Whitehead, L. 2006. Latin America: A New Interpretation. Palgrave, New York and London.

Williams, N., and Vorley, T. (2014). Institutional asymmetry: how formal and informal institutions affect entrepreneurship in Bulgaria. International Small Business Journal, 0266242614534280 .

Wu, W., and Davis, O. A. (1999). The two freedoms, economic growth and development: An empirical study. Public choice, 100(1-2), 39-64.

Yunus, M. (1999). Banker to the Poor. London: Aurum.

Zahra, S. A., Wright, M., and Abdelgawad, S. G. (2014). Contextualization and the advancement of entrepreneurship research. International Small Business Journal, 0266242613519807. 
Tables

Table 1. Calibration criteria

\begin{tabular}{lccc}
\hline Condition & Full in & COP & Full out \\
\hline Microfinance provision & 336 & 105 & 20 \\
Education equality & 82 & 79 & 70 \\
Freedom over life choices & 95 & 70 & 50 \\
Transparency & 66 & 39 & 21 \\
Financial inclusion & 54 & 24 & 10 \\
\hline
\end{tabular}

Table 2. Calibration table

\begin{tabular}{lccccc}
\hline Case & $\begin{array}{c}\text { Microfinance } \\
\text { Provision }\end{array}$ & $\begin{array}{c}\text { Education } \\
\text { Equality }\end{array}$ & $\begin{array}{c}\text { Freedom over } \\
\text { life choices }\end{array}$ & Transparency & $\begin{array}{c}\text { Financial } \\
\text { Inclusion }\end{array}$ \\
\hline Argentina & 0.03 & 1 & 0.59 & 0.46 & 0.05 \\
Bolivia & 0.97 & 0.1 & 0.81 & 0.501 & 0.94 \\
Brazil & 0.04 & 0.23 & 0.51 & 0.65 & 0.14 \\
Chile & 0.83 & 1 & 0.6 & 0.95 & 0.97 \\
Colombia & 0.6 & 0.41 & 0.75 & 0.54 & 0.61 \\
Costa Rica & 0.63 & 1 & 0.93 & 0.82 & 0.15 \\
Dominican Republic & 0.11 & 0.27 & 0.9 & 0.39 & 0.34 \\
Ecuador & 0.78 & 0.45 & 0.55 & 0.43 & 0.72 \\
El Salvador & 0.57 & 0.04 & 0.51 & 0.58 & 0.501 \\
Guatemala & 0.07 & 0.01 & 0.83 & 0.39 & 0.42 \\
Honduras & 0.06 & 0.05 & 0.45 & 0.29 & 0.16 \\
Jamaica & 0.79 & 1 & 0.72 & 0.56 & 0.17 \\
Mexico & 0.38 & 0.47 & 0.67 & 0.501 & 0.88 \\
Nicaragua & 0.08 & 0.02 & 0.78 & 0.26 & 0.45 \\
Panama & 0.08 & 0.99 & 0.9 & 0.54 & 0.09 \\
Paraguay & 0.36 & 0.98 & 0.91 & 0.16 & 0.88 \\
Peru & 0.55 & 0.18 & 0.501 & 0.56 & 0.7 \\
Uruguay & 0.16 & 1 & 0.91 & 0.95 & 0.12 \\
Venezuela & 0.05 & 0.97 & 0.26 & 0.08 & 0.05 \\
\hline & & & & & \\
\hline
\end{tabular}


Table 3. Truth table

\begin{tabular}{lllllll}
\hline $\begin{array}{l}\text { Microfinance } \\
\text { Provision }\end{array}$ & $\begin{array}{l}\text { Education } \\
\text { Equality }\end{array}$ & $\begin{array}{l}\text { Freedom over } \\
\text { life choices }\end{array}$ & Transparency & Cases & $\begin{array}{l}\text { Financial } \\
\text { Inclusion }\end{array}$ & Consist. \\
\hline 1 & 0 & 1 & 0 & 1 & 1 & 1.000 \\
1 & 0 & 1 & 1 & 4 & 1 & 0.997 \\
0 & 0 & 1 & 1 & 2 & 1 & 0.860 \\
0 & 0 & 0 & 0 & 1 & 1 & 0.809 \\
1 & 1 & 1 & 1 & 3 & 1 & 0.775 \\
0 & 0 & 1 & 0 & 3 & 0 & 0.741 \\
0 & 1 & 1 & 0 & 2 & 0 & 0.715 \\
0 & 1 & 0 & 0 & 1 & 0 & 0.626 \\
0 & 1 & 1 & 1 & 2 & 0 & 0.587 \\
\hline
\end{tabular}

Table 4. Solution table

\begin{tabular}{|c|c|c|c|c|}
\hline \multicolumn{5}{|c|}{ Solutions } \\
\hline Configurations & $\mathbf{1}$ & 2 & 3 & 4 \\
\hline Microfinance Provision & & . & & $\otimes$ \\
\hline Education Equality & - & $\bigotimes$ & $\otimes$ & $\bigotimes$ \\
\hline Freedom over life choices & C & & O & $\bigotimes$ \\
\hline Transparency & 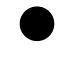 & & - & $\otimes$ \\
\hline Consistency & 0.83 & 0.88 & 0.99 & 0.81 \\
\hline Raw coverage & 0.54 & $\mathbf{0 . 5 2}$ & 0.45 & 0.3 \\
\hline Unique coverage & 0.16 & 0.073 & 0.057 & 0.0 \\
\hline Overall consistency & & 0.78 & & \\
\hline Overall coverage & & 0.73 & & \\
\hline
\end{tabular}

Model: financial inclusion $=\mathrm{f}$ (choices, education, provision, transparency)

$\mathrm{N}=19$; frequency cutoff: 1 ; consistency cutoff: 0.774 
Table 5. Descriptive Solution table

\begin{tabular}{|c|c|c|}
\hline Solution & Conditions & Implications \\
\hline 1 & $\begin{array}{l}\text { Present: Microfinance (economic } \\
\text { freedom); Political Freedom; } \\
\text { Transparency }\end{array}$ & $\begin{array}{l}\text { Financial inclusion amongst low income micro- } \\
\text { entrepreneurs occurs in conditions where MFIs } \\
\text { are willing to lend, entrepreneurs are free from } \\
\text { oppression and corruption. }\end{array}$ \\
\hline 2 & $\begin{array}{l}\text { Present: Transparency, Political } \\
\text { Freedoms } \\
\text { Absent: Education }\end{array}$ & $\begin{array}{l}\text { Financial inclusion amongst low income micro- } \\
\text { entrepreneurs occurs in conditions where } \\
\text { entrepreneurs are free from oppression and } \\
\text { corruption but lack educational opportunities. }\end{array}$ \\
\hline 3 & $\begin{array}{l}\text { Present: Microfinance (economic } \\
\text { freedom), Political Freedom } \\
\text { Absent: Education }\end{array}$ & $\begin{array}{l}\text { Financial inclusion amongst low income micro- } \\
\text { entrepreneurs occurs in conditions where MFIs } \\
\text { are willing to lend and entrepreneurs are free } \\
\text { from oppression but lack educational } \\
\text { opportunities. }\end{array}$ \\
\hline 4 & $\begin{array}{l}\text { Absent: Microfinance (economic } \\
\text { freedom), Political Freedom, Education, } \\
\text { Transparency }\end{array}$ & $\begin{array}{l}\text { Financial inclusion amongst low income micro- } \\
\text { entrepreneurs occurs in conditions where MFIs } \\
\text { are not willing to lend, entrepreneurs not free } \\
\text { from oppression and corruption, and lack } \\
\text { educational opportunities. }\end{array}$ \\
\hline
\end{tabular}

Table 6. Analysis of Necessary Conditions

\begin{tabular}{lcc}
\hline Condition tested & Consistency & Coverage \\
\hline Choices & 0.870639 & 0.555156 \\
Microfinance provision & 0.700276 & 0.818067 \\
Transparency & 0.726891 & 0.630774 \\
Education equality & 0.553890 & 0.454277 \\
$\sim$ Choices & 0.480638 & 0.677310 \\
$\sim$ Microfinance provision & 0.611437 & 0.430017 \\
$\sim$ Transparency & 0.701115 & 0.622923 \\
$\sim$ Education equality & 0.640331 & 0.604870 \\
\hline
\end{tabular}


Appendix A. Correlations

\begin{tabular}{|c|c|c|c|c|c|c|c|c|}
\hline & 1 & 2 & 3 & 4 & 5 & 6 & 7 & 8 \\
\hline \multicolumn{9}{|l|}{1 Portfolio size US\$ } \\
\hline $2 \mathrm{~N}$ MF Clients & $.902 * *$ & & & & & & & \\
\hline 3 SI.POV.NOP25 & 0.429 & $.736 * *$ & & & & & & \\
\hline 4 SI.POV.NOP4 & $.527 *$ & $.815^{* *}$ & $.979 * *$ & & & & & \\
\hline 5 SI.POV.NOP5 & $.550 *$ & $.843 * *$ & $.967 * *$ & $.998 * *$ & & & & \\
\hline 6 SP.POP.TOTL & $.501 *$ & $.796 * *$ & $.931 * *$ & $.976^{* *}$ & $.983^{* *}$ & & & \\
\hline 7 U\$MF/Hab & 0.338 & 0.054 & -0.23 & -0.26 & -0.226 & -0.247 & & \\
\hline $8 \mathrm{U} \$ \mathrm{MF} / \mathrm{MF} \mathrm{CL}$ & -0.222 & -0.341 & -0.366 & -0.352 & -0.322 & -0.293 & 0.252 & \\
\hline $9 \mathrm{MF}$ institutions & $.640 * *$ & $.654 * *$ & $.471 *$ & $.478 *$ & $.484 *$ & 0.414 & 0.198 & -0.433 \\
\hline
\end{tabular}

** Correlation is significant at the 0.01 level (2-tailed).

* Correlation is significant at the 0.05 level (2-tailed).

\section{Appendix B. Raw scores}

\begin{tabular}{lccccc}
\hline Case & Choices & $\begin{array}{c}\text { Equality } \\
\text { education }\end{array}$ & Transparency & $\begin{array}{c}\text { Microfinance } \\
\text { provision }\end{array}$ & $\begin{array}{c}\text { Financial } \\
\text { Inclusion }\end{array}$ \\
\hline Argentina & 72.93 & 91.38 & 34 & 4.1 & 1.56 \\
Bolivia & 82.25 & 72.40 & 35 & 373.4 & 60.04 \\
Brazil & 70.38 & 75.30 & 43 & 12.6 & 12.19 \\
Chile & 73.30 & 86.30 & 73 & 228.1 & 69.04 \\
Colombia & 79.09 & 77.90 & 37 & 136.2 & 32.36 \\
Costa Rica & 91.94 & 84.30 & 54 & 145.5 & 12.44 \\
Dominican Republic & 88.55 & 76.00 & 32 & 44.6 & 21.29 \\
Ecuador & 71.62 & 78.40 & 33 & 203.5 & 37.92 \\
El Salvador & 70.36 & 69.80 & 39 & 126.9 & 29.89 \\
Guatemala & 83.21 & 63.90 & 32 & 31.5 & 24.46 \\
Honduras & 68.53 & 70.43 & 29 & 24.6 & 13.42 \\
Jamaica & 78.05 & 89.40 & 38 & 207.1 & 13.69 \\
Mexico & 75.80 & 78.60 & 35 & 91.1 & 50.28 \\
Nicaragua & 80.50 & 66.70 & 28 & 37.7 & 25.27 \\
Panama & 88.61 & 83.70 & 37 & 35.5 & 7.21 \\
Paraguay & 89.39 & 82.80 & 24 & 88.6 & 50.71 \\
Peru & 70.01 & 74.40 & 38 & 119.4 & 36.61 \\
Uruguay & 88.89 & 89.10 & 73 & 58.4 & 10.15 \\
Venezuela & 63.12 & 82.40 & 19 & 23.8 & 2.6 \\
\hline
\end{tabular}


Appendix C. Descriptive and correlations

\begin{tabular}{lllllllll}
\hline & Min & Max & Mean & SD & $\mathbf{1}$ & $\mathbf{2}$ & $\mathbf{3}$ & $\mathbf{4}$ \\
\hline 1 Choices & 0.26 & 0.93 & 0.68 & 0.19 & & & & \\
2 Microfinance provision & 0.03 & 0.97 & 0.37 & 0.32 & 0.058 & & & \\
3 Transparency & 0.08 & 0.95 & 0.50 & 0.23 & 0.255 & 0.379 & & \\
4 Education equality & 0.01 & 1 & 0.53 & 0.42 & 0.172 & 0.056 & 0.265 & \\
Financial Inclusion & 0.05 & 0.97 & 0.43 & 0.33 & 0.082 & $.626^{* *}$ & 0.025 & -0.252 \\
\hline
\end{tabular}

** Correlation is significant at the 0.01 level (2-tailed).

Appendix D. Cases and solution terms

\begin{tabular}{|c|c|c|c|c|}
\hline Solution 1 & Solution 2 & Solution 3 & Solution 4 & Excluded cases* \\
\hline Chile $(0.6,0.97)$ & Colombia & Bolivia $(0.81,0.94)$ & & Argentina \\
\hline Colombia & $(0.54,0.61)$ & Colombia & & Venezuela \\
\hline $\begin{array}{l}(0.54,0.61) \\
\text { El Salvador }\end{array}$ & $\begin{array}{l}\text { El Salvador } \\
(0.51,0.501)\end{array}$ & $\begin{array}{l}(0.59,0.61) \\
\text { Ecuador }\end{array}$ & & $\begin{array}{l}\text { Dominican } \\
\text { Republic }\end{array}$ \\
\hline$(0.51,0.501)$ & Bolivia & $(0.55,0.72)$ & & Nicaragua \\
\hline $\begin{array}{l}\text { Bolivia } \\
(0.501,0.94)\end{array}$ & $\begin{array}{l}(0.501,0.94) \\
\text { Mexico }\end{array}$ & $\begin{array}{l}\text { El Salvador } \\
(0.51,0.501)\end{array}$ & \multirow{4}{*}{$\begin{array}{l}\text { Honduras } \\
(0.55,0.16)\end{array}$} & \\
\hline Peru $(0.501,0.7)$ & $\begin{array}{l}(0.501,0.88) \\
\text { Peru }(0.501,0.7)\end{array}$ & Peru $(0.501,0.7)$ & & $\begin{array}{l}\text { Panama } \\
\text { Paraguay }\end{array}$ \\
\hline Jamaica $(0.56,0.17)$ & & & & \\
\hline $\begin{array}{l}\text { Costa Rica } \\
(0.63,0.15)\end{array}$ & Brazil $(0.51,0.14)$ & & & \\
\hline
\end{tabular}

*Cases with low financial inclusion $(<0.5)$ and inconsistent combinations of conditions 